\title{
Comparative Study on Evaluations Conducted by Medical Doctors and Social Workers in which the Adapted Brazilian Functionality Index for Granting Retirement to Persons with Disability Was Applied
}

\begin{abstract}
Rosylane Nascimento das Mercês Rocha1, Francisco Cortes Fernandes ${ }^{2}$, Josierton da Cruz Bezerra ${ }^{3}$, Rui Nunes ${ }^{4}$
\end{abstract}

\section{Abstract}

Objective: The present study sought to assess whether any statistically significant differences exist between evaluations conducted by medical doctors and those by social workers within the National Social Security Institute (INSS), regarding identification of disability using the adapted Brazilian functionality index to grant retirement.

Method: To do this, an analytical investigation was done using the official INSS database for the period from October 2013 to January 2016, regarding evaluations to confirm disability among workers who were insured through the INSS. The analysis was conducted using the $R$ software, version 3.4.1. A concordance index, significance analysis and the Pearson correlation test were applied. The sensitivity and specificity of the evaluations made by doctors, by social workers and by both were calculated. A rating index was obtained by dividing the result from the doctors' evaluations by the result from the social workers' evaluations.

Results: The correlation analysis using the $\mathrm{R}$ software showed that there was no statistical difference between the evaluations conducted by medical doctors and social workers. However, differences were observed in relation to calculation of the sensitivity of the evaluations, and in the analyses on the rating index and standard deviation between the doctors' and social workers' evaluations, especially in the
1 University of Porto, Portugal; State Planning Department of the Federal District, Brasília, Brazil.

2 Pontifical Catholic University of Goiânia, Brazil

3 National Social Security Institute, Rio Grande do Norte, Brazil.

4 University of Porto, Portugal

\section{Contact information:}

Rosylane Nascimento das Mercês Rocha.

”r rosylanerocha@yahoo.com.br 
domains of sensory function, domestic life and education, work and economic life.

Conclusions: This study demonstrated that there is a difference between evaluations conducted by medical experts and by social workers, which can be explained in terms of each professional's interpretation of what is defined in the manual. The criteria used to define the rules for obtaining the benefit should be discussed. We highlight that the prerequisite for identifying a disability is that an impairment should be characterized by means of the International Classification of Diseases (ICD-10), which is a medical prerogative.

\section{Keywords}

Comparative Study; Internatiomal Classification of Functioning, Disability and Health; Disability Evaluation; Physicians; Social Workers.

\section{Introduction}

In Brazil, 23.9\% of the population present some form of physical, auditory, motor, mental or intellectual disability, which represents approximately 45,606,048 Brazilians [1].

Several institutions representing this disabled population have been created with the aim of implement benefits and ensuring improvement of the quality of life of these people. The legislation has evolved to guarantee their rights.

The different rules that are applied so that people with disabilities can make use of social benefits allow broad interpretations. Thus, people with mild disabilities, without any significant impairment of functionality, can also benefit from the legislation. They often occupying the place of people with severe disabilities and functional limitations [2].

Brazilian law no. 142, of May 8, 2013, classifies people with disabilities into low, moderate and severe categories, which consequently reduces the length of time for which they need to make social security contributions towards their retirement by two, six and ten years, respectively $[3,4]$. This evaluation is done by applying the adapted Brazilian functionality index (IF-BrA), which was published in Interministerial Ordinance no. 1 of January 27, 2014 [5] (AGU/MPS/MF/SEDH/MP). Disability is identified from a biopsychosocial perspective, following the recommendations of the convention on disabled people's rights [6].

The concept that an individual is disabled is defined as a situation of presentation of long-term impairment of a physical, mental, intellectual or sensory nature that, in interaction with various barriers, may obstruct that individual's full and effective participation in society under conditions of equality with other people $[7,8]$.

The IF-BrA is applied by medical experts and by social workers within the National Social Security Institute (INSS) in two different stages. The evaluation process begins with the medical expert, through identification of the impairment in accordance with the International Classification of Diseases (ICD). This instrument presents seven domains 
based on the International Classification of Functioning, Disability and Health (ICF), namely: sensory function; communication; mobility; personal care; domestic life; education, work and economic life; and socialization and community life. It evaluates 41 activities that relate to these domains $[5,6]$. The evaluation results in a score for the domains given by each professional. The sum of these responses generates a cutoff point that is adopted as a limit for identifying and classifying the disability, using the following scores: severe disability: 5739 points; moderate disability: between 5740 and 6354; mild disability: between 6355 and 7584; and insufficient impairment to obtain the benefit: greater than or equal to 7585 .

The objective of the present study was to assess whether any statistical differences exist between the analyses conducted by medical experts and by social workers within the INSS, regarding identification of disability, using the adapted Brazilian functionality index to grant retirement.

The justification for this study came from the fact that no investigations using this approach exist within the literature. This study can therefore contribute towards discussion of evaluations, identification methodologies, inclusion and improvement of the quality of life of people with disabilities.

\section{Material and Methods}

An analytical investigation was conducted using secondary data from the INSS database covering the period from October 2013 to January 2016, regarding evaluations on insured workers who requested the benefit of special retirement due to a disability. Based on the dataset that had been made available by the INSS (the same as used by the team that elaborated the (F-BrA), an analytical investigation was conducted to compare the evaluations of medical experts and social workers. The R software, version 3.4.1, was used to analyze summary measurements (relative frequency; test definitions; hypothesis tests; significance level; Pvalue; and correlation coefficient, i.e. Pearson correlation) and to perform descriptive analysis and correlation analysis (per domain and per type of disability). After this analysis, the correspondence between the evaluations of the medical doctors and social workers was assessed by applying a concordance index to compare similarities. Correlation coefficients measure the degree to which two variables tend to change together, thus describing the strength and direction of this relationship. Hence, the test was conducted under the following hypotheses:

$\mathrm{HO}$ : There is no linear association between the opinions of the medical doctors and social workers.

$\mathrm{H} 1$ : There is a linear association between the opinions of the medical doctors and social workers.

After applying the correlation coefficient, significance analysis was conducted. In this analysis, the response variable was considered to be the type of disability indicated according to the medical doctor's evaluation (severe, moderate, mild or no disability), while the explanatory variables were the seven domains (sensory function; communication; mobility; personal care; domestic life; education, work and economic life; and socialization and community life). The domains considered were analyzed equally, since both professionals were asked the same questions.

Spearman's correlation was used in this analysis to measure the correlation between the mean values of the seven domains, with a significance level of a equal to 0.05 (Table 2).

The model basically presents two values. From the $t$ statistical value, the $p$-value was calculated considering $\alpha=5 \%$. For the explanatory variables, the closer the $t$ value was to zero, the more relevant that variable would be for explaining the model. Regarding the response variables, the closer they were to the $t$ value, the more likely the occurrence 
of that specific response would be. A p-value lower than $\alpha$ would indicate that this variable (either explanatory or response) was statistically significant in the model, meaning that it is necessary.

With the aim of deepening the comparative study, an index was elaborated by dividing the resultant relative frequency from the medical expert by the relative frequency score from the social worker. When this index was 1, the evaluations presented total similarity. When the results were either above or below 1, the evaluations were dissimilar.

Moreover, the sensitivity and specificity of the evaluations made by the doctors, by the social workers and by both were calculated. The sensitivity was calculated using the percentages of evaluations for disability that were positive, which the medical doctor, social worker and both of them had made, as shown in Table 4.

The present study formed part of a research project that had been presented to and approved by the Ethics Committee of the Higher School of Health Sciences of the Research and Teaching Foundation of the State Health Department of the Federal District, under CAAE no. 82617317.0.0000.5553.

\section{Results}

The summary measurement data analysis comparing the degrees of disability is described in Table 1. The correlation analysis demonstrated that there were no statistically significant differences regarding the evaluations conducted by either the medical expert or the social worker, as shown in Table 2.

Regarding the degree of disability in the evaluations of the medical doctors and social workers, the index applied yielded the following results: 25 $=0.54 ; 50=1.36 ; 75=0.77 ; 100=3.32$. This demonstrates that there were differences in the results from the evaluations of these two professionals. The results for the index applied to all activities, with its standard deviation, in the various domains, are presented in Table 3.
Table 1. Degree of Disability: Evaluation by Medical Doctors and Social Workers.

\begin{tabular}{l|c|c|c|c}
$\begin{array}{l}\text { Degree } \\
\text { of } \\
\text { disability }\end{array}$ & $\begin{array}{c}\text { Absolute } \\
\text { frequency }\end{array}$ & $\begin{array}{c}\text { Relative } \\
\text { frequency }\end{array}$ & $\begin{array}{c}\text { Absolute } \\
\text { frequency }\end{array}$ & $\begin{array}{c}\text { Relative } \\
\text { frequency }\end{array}$ \\
\hline Severe & 1635 & 10.90 & 2986 & 19.90 \\
\hline Mild & 6235 & 41.56 & 4562 & 30.41 \\
\hline Moderate & 5294 & 35.29 & 6851 & 45.67 \\
\hline No & 1813 & 12.08 & 545 & 3.63 \\
disability & 23 & 0.15 & 56 & 0.37 \\
\hline No report & 23 & & &
\end{tabular}

Table 2. Spearman correlation to measure the correlation between the mean values of the seven domains.

\begin{tabular}{|l|c|c|}
\hline \multicolumn{1}{|c|}{ Domain } & p-value & $p$ \\
\hline Sensory function & $2.2-16$ & 0.72 \\
\hline Communication & 61.47 & 0.67 \\
\hline Mobility & 66.47 & 0.65 \\
\hline Personal care & 64.26 & 0.55 \\
\hline Domestic life & 70.05 & 0.55 \\
\hline Education, work and economic life & 76.19 & 0.42 \\
\hline Socialization and community life & 61.47 & 0.44 \\
\hline
\end{tabular}

Table 3. Comparison index between the evaluations of medical doctors and social worker.

\begin{tabular}{|l|c|c|}
\hline \multicolumn{1}{|c|}{ Domain } & Index & 1 sigma \\
\hline Sensory function & 0.56 & 0.44 to 1.56 \\
\hline Communication & 0.18 & 0.82 to 1.18 \\
\hline Mobility & 0.29 & 0.71 to 1.29 \\
\hline Personal care & 0.23 & 0.77 to 1.23 \\
\hline Domestic life & 0.45 & 0.55 to 1.45 \\
\hline Education, work and economic life & 0.42 & 0.58 to 1.42 \\
\hline Socialization and community life & 0.29 & 0.71 to 1.29 \\
\hline Total & 0.34 & 0.66 to 1.34 \\
\hline
\end{tabular}

From comparing the medical, social and combined evaluations through the sensitivity calculation, the following sensitivity results were obtained - Table 4: combined evaluation, 97.73\%; medical evaluation, 87.89\%; and social worker evaluation, 97.37\%. This difference in sensitivity required a more detailed analysis of the results, in order to identify what these differences were. 
Table 4. Specificity and sensitivity, as relative frequencies.

\begin{tabular}{|l|c|c|c|}
\hline \multirow{2}{*}{ Evaluator } & $\begin{array}{c}\text { Disability } \\
\text { detected }\end{array}$ & $\begin{array}{c}\text { Does not have } \\
\text { disability }\end{array}$ & $\begin{array}{c}\text { Total } \\
\text { evaluated }\end{array}$ \\
\cline { 2 - 4 } & $\%$ & $\%$ & $\%$ \\
\hline $\begin{array}{l}\text { Social } \\
\text { worker }\end{array}$ & 96.353 & 3.647 & 100 \\
\hline $\begin{array}{l}\text { Medical } \\
\text { doctor }\end{array}$ & 87.895 & 12.105 & 100 \\
\hline Both & 97.730 & 2.270 & 100 \\
\hline
\end{tabular}

\section{Discussion}

The evaluations of degree of disability, carried out by the medical expert and social worker, as demonstrated in Table 1, were similar based on the correlation test. However, in comparing these professionals' evaluations together, there were significant results regarding sensitivity, as shown in Table 4.

Thus, application of the index made it possible to observe divergences in the evaluations between these two professionals, which had not been shown in the statistical inference. The explanation for the similarity between the evaluations from an inferential statistical perspective seems to be related to the rule that was used to establish the degree of disability. This indicates the possibility that the professionals involved in the evaluation had divergent views on the degrees of disability.

There were conceptual differences in the analyses by the medical experts and social workers, especially regarding the domains of sensory function, domestic life and education, work and economic life in Table 2. The communication domain presented the lowest rate of difference. In conducting the evaluation on all the domains together, a value of 0.34 was obtained, which indicates that there was a difference in the evaluation between the two groups (values between 0.66 and 1.34).

Given the results in Table 2, all the domains were considered relevant. The domains of socialization and community life, education, work and economic life and personal care were considered to have the highest relevance. Regarding the response variable, the most probable response obtained was mild disability, followed by severe, then moderate and, finally, no disability. The correlation and significance analyses that were conducted did not show any differences between the evaluations carried out by the medical experts and social workers, regarding application of the rules for fitting into a situation of retirement according to the degree of disability presented.

\section{Conclusion}

The present study demonstrated the differences between the results from evaluations conducted by medical experts and social workers, despite the criteria described in the IF-BrA manual.

Thus, the concepts of degree of disability between the medical expert and social worker can be considered to be variable, and this would explain the different interpretations of each professional regarding what is defined in the manual. Moreover, there is a need to discuss the criteria used to define the rules for obtaining the benefit, in order to improve their accuracy.

Lastly, it is important to highlight that the prerequisite for identifying a disability is that the impairment needs to be characterized through the International Classification of Diseases (ICD-10), which is a medical prerogative and is the starting point for the process of evaluating disability.

\section{References}

1. Brasil. Decreto no 6949, de 25 de agosto de 2009 [Internet]. [acesso 26 Mai 2018]. Disponível em: http://www.planalto.gov. br/ccivil 03/ ato2007-2010/2009/decreto/d6949.htm

2. Brasil. Censo Demográfico 2010: Características gerais da população, religião e pessoas com deficiência. Instituto Brasileiro de Geografia e Estatística. [Internet]. [acesso 26 Mai 2018]. Disponível em: http://www.ibge.gov.br/home/estatistica/ populacao/censo2010/caracteristicas religiao deficiencia/ default caracteristicas religiao deficiencia.shtm 
3. Rocha RNM. Perícia Médica em candidato portador de necessidade especial para concurso público: aspectos clínicos e científicos sobre a deficiência de incapacidade funcional e deficiência física [Monografia]. Brasília (DF): Universidade Gama Filho, Fundação Unimed; 2011.

4. Brasil. Lei Complementar no 142, de 8 de maio de 2013. [Internet]. [acesso 26 Mai 2018]. Disponível em: http://www. planalto.gov.br/ccivil 03/Leis/LCP/Lcp142.htm

5. Brasil. Relatório Final. Elaboração de Instrumento de Classificação de Funcionalidade de Pessoas com Deficiência para Cidadãos Brasileiros. Secretaria de Direitos Humanos. Secretaria Nacional de Promoção dos Direitos das Pessoas com Deficiência, 2012.

6. Franzoi AC, Xerez DR, Blanco M, Amaral T, Costa, AJ, Khan P, et al. Etapas da elaboração do Instrumento de Classificação do Grau de Funcionalidade de Pessoas com Deficiência para Cidadãos Brasileiros: Índice de Funcionalidade Brasileiro-IF-Br. Acta Fisiatrica, 20(3), 164-170.

7. Brasil. Decreto no 6949, de 25 de agosto de 2009 [Internet]. [acesso 26 Mai 2018]. Disponível em: http://www.planalto.gov. br/ccivil 03/ ato2007-2010/2009/decreto/d6949.htm

8. Brasil. Lei 13146, de 6 de julho de 2015 [Internet]. [acesso $26 \mathrm{Mai}$ 2018]. Disponível em: http://www.planalto.gov.br/ccivil 03/ ato2015-2018/2015/lei/l13146.htm

Publish in International Archives of Medicine

International Archives of Medicine is an open access journal publishing articles encompassing all aspects of medical science and clinical practice. IAM is considered a megajournal with independent sections on all areas of medicine. IAM is a really international journal with authors and board members from all around the world. The journal is widely indexed and classified Q2 in category Medicine. 